\title{
Harmonizing the Community: An Intellectual Role of Ulama in Modern Indonesia
}

\author{
Moeflich Hasbullah \\ (UIN Sunan Gunung Djati, Bandung; moef has@,uinsgd.ac.id)
}

\begin{abstract}
Abstrak
Artikel ini menganalisis peran intelektual ulama sebagai perantara budaya dalam masyarakat dari beberapa tabap dalam sejarah Indonesia. Bab-bab terpenting dalam sejarah Indonesia secara umum dapat dibagi menjadi lima periode: Pertama, periode masuknya Islam dan perkembangan awal islamisasi. Kedua, masa penjajahan. Ketiga, era era modern, yaitu munculnya gerakan modern dalam Islam di awal abad ke-20. Keempat, periode kemerdekaan revolusioner, dan kelima, periode pasca-kemerdekaan. Artikel sosio-historis ini melibat bahwa ulama di setiap periode ini adalah aktor utama sejarah dan menentukan arah perkembangan bangsa Indonesia. Khusus untuk bagian 'pembangunan komunitas' dalam penelitian ini, kasus peran seorang ulama yang merupakan kepala desa di Rancapanggung, Cililin, Bandung Barat pada 1930-an.
\end{abstract}

\section{Kata kunci: Peran pemimpin, keharmonisan sosial, islamisasi Indonesia}

\begin{abstract}
This article analyzes the ulama's intellectual role as a cultural broker in society from several stages in Indonesian history. The most important chapters in Indonesian history can generally be divided into five periods: First, the period of the entry of Islam and the early development of Islamization. Second, the colonial period. Third, the era of modern era, namely the emergence of modern movements in Islam in the early 20th century. Fourth, the revolutionary period of independence, and fifth, the post-independence period. This socio-historical article sees that the ulama in each of these periods is the main actor of history and determines the direction of the development of the Indonesian nation. Specifically for the 'community building' section of this study, the case of the role of a cleric who was the village head in Rancapanggung, Cililin, West Bandung in the 1930s.
\end{abstract}

Keywords: The role of leaders, social harmony, the Islamization of Indonesia

\section{A. INTRODUCTION}

Fachri Ali, a Muslim scholar political observer, in his column in Tempo October 19, 1991, asking a question which he himself admitted as fetched: "What will happen to Indonesia without Cak Nur and Gus Dur?" In its own context, namely the 
discussion about the development of cultural Islam which has been strongly symptomatic in Indonesia since the late 1980s, and the movement has had a smooth and wide-ranging impact of Islamization until now, Fachri's question can be understood. The two figures are indeed two prominent Islamic figures who are not only prominent in Indonesia but also internationally. Nurcholish Madjid (Cak Nur) and Abdurrahman Wahid (Gus Dur) are two modern Indonesian Islamic thinkers whose thoughts are both the pioneers of cultural Islam.

In addition to being the originators of cultural Islam, the two have four other similarities: First, the figure is controversial. By some Muslims, Cak Nur is claimed to be an "Orientalist accomplice" because one of his teachers in America was Leonard Binder, a Jewish author of Islamic Liberalism: A Critique of Development Ideologies (1988), although he also studied at Fazlur Rahman. Whereas Abdurrahman was accused of being close to Israel. He is close to Israeli Prime Minister Benjamin Netanyahu and is a board member of a religious and peace organization based in Israel. Second, in addition to the figure, his thoughts are the same, both are controversial. Cak Nur was controversial because of his thought reform movement since the 1970s, and Gus Dur was controversial because of his "secular liberalism" ideology. In cases involving Muslims, Gus Dur, who is the leader of the cleric, often opposes the flow of religious religious emotions. He often tends to defend non-Muslim groups. In discussing the flow of Islamic thought, analysts classify the two together, namely thinkers of Islamic neomodernism. Third, both have the same "blue blood": Cak Nur was once referred to as "young Natsir" who inherited the traits and greatness of Mohammad Natsir (Muslim democrat) and Abdurrahman inherited the fame of his grandfather $\mathrm{KH}$ 
Hasyim Asy'ari, the founder of the NU ulama year 1926. Fourth, both of them came from pesantrens (Islamic boarding schools). Cak Nur is a Gontor Islamic Boarding School alumni who grew up in a Masyumi environment, while Gus Dur was a NU kyai (religious scholar) family.

Taking inspiration from the story of the struggle of the national hero KH. Zainal Mustofa, this paper will not answer or review the question, but rather ask a question that is more important than Fachri Ali's question above, namely: "What would happen to Indonesia without religious scholars?" This question besides being more realistic is also very important to be answered and known by Muslims. This paper tries to answer this important question.

\section{B. LITERATURE REVIEW}

\section{Ulama: The spreaders of Islam in the Islamic Archipelago}

Islam expanded to all corners of the earth, to Southeast Asia and Indonesia because of the role of scholars. This clerical function is attached to the guardians, traders (merchants) and kings who spread Islam. In the period of Islamization, especially between the 13 th to 17 th centuries, these three figures were united and difficult to separate. The saints are also respected and aristocratic. The rulers, aristocrats, and kings are merchants who control the trade routes, and the merchants are also Islamic propagators. That is what makes Islamization effective and successful. They spread Islam to the population, the upper classes and then to the kings through propaganda, trade relations, cultural arts and marriage with local residents. Then, the development of Islam became conducive and effective because it 
was supported by three other aspects: the condition of Hindu kingdoms that were experiencing chaos, decline and then collapsed (Srivijaya, Majapahit and Mataram), the vast trade routes in Southeast Asia controlled by Muslim merchants, and elements of Islamic teachings that do not recognize caste as in Hinduism. The absence of caste in Islam caused the human dignity of the indigenous population to convert to Islam, unlike their previous situation in Hinduism which was worthless (De Graaf \& Pigeaud, 1985; Reid, 1993).

For this method of Islamization, it has become a historical axiom among native and foreign historians that Islam entered and spread in Indonesia by peaceful means. In its development, namely in the next stage of Islamization, the ulama functioned itself as a "cultural broker." Cultural broker or cultural agent is the term Clifford Geertz (1959-60: 228-249), an American anthropologist, who describes the role of scholars as a link between local communities and the outside world (foreign influences in the form of politics, values and culture) and dynamics tensiontension arising from the interaction process of these influences and values. The role of 'liaison' and 'dynamism' shows the social and political role of the ulama who expertly pack and process interactions and tensions that point to a peaceful path in the process of Islamization, or could be called 'Indian' way of religious proselytization (Rahman, 2013).

As a result, the work of these amazing trustees or scholars, Indonesia is now the largest Muslim country in the world with 213.4 million Muslims (Comparison: AlJazair 32.2 million, Bangladesh 130 million, Egypt 73 million, Ethopia 24, 6 million, European Union 14.3 million, India 174.7 million, Malaysia 14.5 million, Morocco 
32.7 million, Pakistan 160.8 million, Turkey 69 million, Uzbekistan 23.6 million, Yemen 20.5 million). Besides being the biggest, it is recognized that Indonesian Islam is an example of a Muslim nation that is tolerant, open, moderate and democratic so that it has the potential to become the center of world Islam in the future (Hasbullah, 1993).

\section{Scholars: Leader of Resistance to Colonial}

When the influence of Islam was continuing to expand in the archipelago politically and culturally until the 17 th century as the labors of the ulama, the penetration of foreign powers into European desires of colonialism and imperialism began with the fall of Malacca into the hands of the Portuguese in 1511, followed by the arrival of ships Spanish ships to the Philippines, North Kalimantan, Tidore, Bacan and Jailolo in 1521 and the Dutch trade organization VOC in 1602 to the waters of Banten (Indonesian National History, pp. 29-65). During the process of colonization, European powers came and went, to drain the wealth of the Indonesian people through political and economic conquests. Humanitarian crimes in the form of foreign powers that colonize and the lust of colonialism and imperialism which deplete the nation's wealth, of course must be resisted with all their might. The results of the ulama's hard work to Islamize the inhabitants of the archipelago in peace and harmony for centuries certainly cannot be disturbed and must be defended. This is where, again the scholars show their fangs and strength. Ulama not only teach the afterlife but exemplify courage, anti-colonialism, not afraid to die and teach how expensive beliefs and dignity. 
Thus, since the 16th century resistance after resistance began to be demonstrated from the failed attack of Pati Unus against the Portuguese in 1513 to its peak in the 19th and mid-20th centuries. The stage of Indonesian history witnessed a series of stories of struggles that were initiated, mobilized and led by scholars. The most colossal for example the Java War. This war, led by Pangeran Diponegoro (1825-1830), had for five years sparked popular resistance in almost all parts of Java; The Paderi War in West Sumatra, led by scholars who had the title "Tuanku" namely Tuanku Imam Bonjol, Tuanku Tambusai and Tuanku nan Cleverly, respectively from 1821 to 1837; Then the War of Sumatra and Kalimantan (1821 - 1838); The Banjarmasin War (1857-1862); The Cilegon Jihad and the Banten Peasant Rebellion in 1888 were exhaled by the tarekat movement of Qadiriyah wan Naqsyabadiyah; The resistance of the Acehnese people in the Aceh War led by Cut Nyak Dien from 1873 to 1942 . In general, studies of ulama's resistance to colonial rule abounded. Among them are Sartono Kartodirjo's books including, The Protest Movements in Rural Java (1978), Banten Peasants' Uprising 1888 (1984), Karel Steenbrink, Some Aspects About Indonesian Islam in the 19th Century (1984), Ibnu Qoyim, Ulama in Indonesia in Indonesia in End of the 19th Century and Early 20th (1994), and so on. Regarding the relationship between ulama and power, Ibnu Qoyim noted that colonial repressive politics gave birth to two mainstream differentmovements. First, the "revolutionary" movement, second, "evolutionary." The revolutionary movement manifested in the movements of resistance and rebellion against the Dutch authorities as mentioned above. The evolutionary movement metamorphoses the Islamic education movement in pesantren, the development of indigenous 
knowledge, the deepening of religious life, the improvement of local human resources and other cultural forms.

In the 20th century in the Sundanese tatar, also erupted several rebellions carried out on the scholars. Among them, the Cimareme Rebellion (Cikendal, Leles) on Monday, July 7, 1919 led by Haji Hasan. Disappointment after disappointment over the oppression, abuse and injustice of the Dutch government, culminating when Haji Hasan and the farmers refused orders to sell rice to the Dutch colonial government at a very low price, far below the market. Haji Hasan was surrounded by 67 soldiers and police forces, he and his followers were shot by Company troops (Sundanese Encyclopedia, pp. 164-165). Then KH. Yusuf Taujiri, a cleric activist for the independence revolution from Pesantren Cipari Garut, who was arrested and detained several times, because of his activities that threatened the Dutch and Japanese governments. Then, the heroic story is stirred by warrior clerics from the Sukamanah Islamic Boarding School, Tasikmalaya, KH. Zainal Mustofa. As a cleric who does not know fear, in his lectures always criticize the Dutch and Japanese governments with a scathing and open. He refused to do seikerei, which is respectfully bowing to Tokyo to respect Tenno Heika. So he became a subscription in and out of prison. In the end, he and his students carried out an uprising against the Japanese government on February 25, 1944, which killed 163 people dead and injured, including himself a martyr in the rebellion.

There are too many heroic stories of the ulama in carrying out resistance and rebellion against the colonialists in Indonesia. We see, armed resistance and open rejection of colonialism is almost entirely carried out by Muslims led by ulama. This 
historical fact shows the great role of the ulama in Indonesia who not only taught religion but also taught building self-esteem. They sacrifice their body and soul for the struggle for independence. The scholars do not deserve the slightest doubt of nationalism, patriotism and heroism.

\section{METHOD}

This study seeks to examine historical facts that can be built in a more comprehensive analysis of the role of ulama in Indonesian history. The issue of ordering, path dependence, contingent choices and alternative evaluations are all important in the process of building that fact and are an important part of this social history research (Kipping, 2014). In this study it is stated that time and place (context) really make a difference in the structure and process of historical meaning, that the structure and process of the past influence the results and that recognition of the appropriate context is very important in understanding and theorizing in national history (Rahman, 2016). It was further said that attention to these problems led to a new conception of the nationalization of the role of intellectuals.

This paper follows the principle of the historian Timothy Snyder (2010). Namely: (1) that the historical method is in accordance with the study of functional sociology; (2) that choices and alternatives at a particular point in time are at the core of this process; (3) that the role of sequence and time is central; and (4) that the comparative method is an aid to understanding the historical meaning process. 


\section{FINDINGS AND DISCUSSION}

\section{Early Period of the 20th Century}

The decline of colonial power due to some resistance and great warfare that occurred in the 19th century, became a setting socio-political for the emergence of modern organizations towards Indonesian independence. The establishment of modern political and religious organizations into the 20th century, again, was marked by the important role of scholars such as KH. Sammanhoeddi, HOS. Cokroaminoto, KH. Agus Salim, KH. Ahmad Dahlan, KH. Hasyim Asy'ari and others. The modern organizations that emerged into the early 20th century were the Islamic Trade Association (SDI) founded in 1905 by Kyai Haji Samanhoeddi, Jamiatul Khair also founded in 1905 by some sayid (Arabian clerics) such as Sayid Muhammad Al-Fachir, Sayid Muhammad bin Abdullah bin Sjihab, Sayid Idrus bin Ahmad, and others. The most important leadership of Jamiat Khair was during the time of Sheikh Ahmad Soorkatti from Sudan. Until 1915 the membership reached 1,000 people. Then also stood Al-Irshad founded by Sheikh Umar Manggus, Saleh bin Ubeid Abdad, and others. Then stood Persyarikatan ulama (1911), Islamic Syarikat (1912), Muhammadiyah (1912) founded by KH. Ahmad Dahlan, Islamic Unity (1923) by Haji Zamzam and Haji Muhammad Yunus, and Nahdlatul Ulama in 1926 by KH. Hasyim Asy'ari (Noer, 1985).

Since the beginning of the 20th century until now, from these modern Islamic mass organizations, there are two things that need to be noted. All of the mass organizations were founded by Islamic scholars and activists. Of all of them, there are three organizations with a very large number of followers, namely Sarekat Islam 
(SI) until the period leading up to independence and NU and Muhammadiyah until now. These three organizations greatly colored the direction and development of Indonesia's history. In the teens, SI whose membership was mass, the number reached millions and became the "parent" of several variants of other Islamic organizations that emerged afterwards. In its annual congresses, from the first to the sixth in 1921 in Surabaya, Deliar Noer (1985: 140) described the number of SI delegates present giving a vote indicating the number of SI memberships in those years:

It can be recorded in relations a sound decision on this issue that the party congress had greatly shrunk. About eighty local Sarekat Islam with 860,000 members sent their representatives to the first National Congress in Bandung in 1916; 71 units with 825,000 members to the second National Congress in Jakarta in 1917; 87 units with 450,000 members to the third National Congress in Surabaya in 1918; 83 units with 2.5 million members to the fourth Congress in Surabaya in 1919; 53 units to the Fifth Congress in Yogyakarta in May 1921 and 63 units to the Sixth Congress in Surabaya in October 1921.

With such numbers imagine the involvement and commitment of the scholars towards the destiny of the nation and state. Their time is spent thinking and contributing their energy and thoughts for public education and the independence of the Indonesian nation and state.

\section{Independence Revolution}

In the process of proclamation and independence revolution, especially at the state level, the ulama did not present themselves. This is because it is not the territory. Technical affairs and work to take care of the state is the territory of a new generation of modern politicians such as Soekarno, Hatta, Syahrir and his generation. 
The cleric places his place in society and integrates with their lives, not in the seat of government or at the state elite level. Their presence in the state administration area is quite represented by some representatives of Islamic figures. On the other hand, in the period leading up to independence, political groups had experienced very broad differentiation. Various political groups, aspirations and ideologies emerge with their respective interests. Suddenly, a small minority group whose name is unknown and is not absent in the history of the struggle to drive out colonial invaders, objected to the first precepts of Pancasila which had been ratified in the constituent assembly, namely: "A Divinity with the Obligation to Run Islamic Sharia for the adherents." The clause that reads "the government guarantees the implementation of Islamic law for its adherents" written in the preambule is debated. This section was actually discussed at the beginning of the trial and approved by the trial. At the same time, when the constituent assembly was dissolved in 1959 by President Sukarno, at that time the trial had already completed $90 \%$ of the discussion. The last $10 \%$ of the debate is longer, tough and difficult, namely discussing the most crucial of all trial material. The $10 \%$ is about the basis of the state, namely whether Indonesia should be based on Islam or Pancasila. The constituent court proceeded 57 days until 18 August 1959 (Ansari, 1981; Maarif, 1987).

It is very reasonable and appropriate, the relentless struggle of hundreds of years of scholars to drive out the invaders at the expense of their body and soul, was given a special article for Muslims, which is like the complete verse one of the Pancasila as above. But what happened was not like that. This is an irony of history. How could demands that are "unclear" from whom and from which direction be accepted by the 
congregation? But, moderate Islamic figures in Committee 9 namely Ki Bagus Hadikusumo, KH. Wachid Hasyim, Mr. Kasman Singodeimedjo, Mr. Teuku Mohammad Hassan and Sukarno themselves showed the greatness of their souls. They accepted the "mysterious demand" for one big reason: the Indonesian nation and state were fully divided. And, many Muslims feel that the struggle of the ulamas for hundreds of years was "sacrificed" in only about 15 minutes of Muhammad Hatta's meeting with the mysterious Christian envoy.

\section{Post-Independence Period}

After the independence, two Islamic organizations from the above mentioned, are still alive and reaching the peak of their glory, both in membership, programs, preaching, education and politics, namely NU and Muhamamdiyah. The number of NU followers is now thought to reach 30 million, and Muhammadiyah 28 million. By this number, NU and Muhammadiyah are the largest Islamic organizations in the world. The membership of the Muslim Brotherhood in Egypt led by Hasan AlBanna has recorded 2,000 branches with 500,000 active members while Jami'ah alIslamiyah in Pakistan led by Abul A'la Maududi is smaller than that.

By that much amount, of course the effect is also extraordinary, that it is impossible to discuss or see Indonesian Islam by not involving or ignoring the two biggest mass organizations. Interestingly, these two largest Islamic mass organizations seem to divide the work area with different identities and work programs as illustrated in the following table: 


\begin{tabular}{|c|c|c|}
\hline Aspects & NU & Muhammadiyah \\
\hline Members $( \pm)$ & 30 million & 28 million \\
\hline Leadership & $\begin{array}{l}\text { Traditional Kyai / } \\
\text { Ulama }\end{array}$ & Scholars / urban Ulama \\
\hline Base / work areas & Rural & Urban \\
\hline $\begin{array}{l}\text { The scientific basis } \\
\text { of }\end{array}$ & $\begin{array}{l}\text { the Yellow Book (the } \\
\text { inheritance of classical } \\
\text { scholars) }\end{array}$ & "White Book" (modern sciences) \\
\hline $\begin{array}{l}\text { The nature of the } \\
\text { movement }\end{array}$ & $\begin{array}{l}\text { Defending the tradition } \\
\text { of }\end{array}$ & Renewal of \\
\hline Thought Religion & Traditionalism & Modernism \\
\hline $\begin{array}{l}\text { Educational } \\
\text { Institution }\end{array}$ & Pesantren & Schools School \\
\hline Economic & Temporal Programs & $\begin{array}{l}\text { Business Charities (schools, } \\
\text { hospitals, colleges etc.) }\end{array}$ \\
\hline
\end{tabular}

This is a general description, not absolute. In certain cases, there is the same identity, or upside down.

The significance of the number and size of such an organization has naturally created strong assumptions: (1) Indonesia is Islam (its own number $\pm 90 \%$ of the total population of Indonesia), (2) it is impossible to understand Indonesia without 
understanding Islam, (3) the whole process social, political, economic and cultural processes related to Islam, and, in other words, (4) it is impossible to release NU and Muhammadiyah in understanding, learning and making political policies concerning Indonesian Islam. As a result, this is an extraordinary achievement of scholars who have made Islam inseparable from Indonesia.

\section{Community Building}

After the national discussion above, the time has come to portray the ulama as a local community figure. This is because the ulamas are usually community builders, wherever they are. The following is the story of an ulama who built a village, namely Rd. Haji Mukhtar in Cililin, West Bandung. Rd. Haji Mukhtar was the Village Chief of Rancapanggung, from 1930 to 1942, when the Japanese occupation had just begun.

According to the Rancapanggung village website, Cililin, in 1930, in Jakarta a National Faction in the People's Council of ten members was formed and was chaired by M. Husni Thamrin with the aim of ensuring the attainment of national independence in the shortest possible time. Simultaneously with the incident, Rancapanggung Village, Cililin District, Bandung, already had a village head named Rd. H. Mukhtar without any election but appointed directly by the community with consideration seen from the authority and strong influence in the eyes of the Dutch colonial government.

The Rancapanggung region in the 1930s, did not yet have village government offices and village markets. Rd. H. Mukhtar was appointed as the Head of the Rancapanggung Village located on the edge of the Rancapanggung Highway, 
covering an area of approximately 4,000 meters in the interests of the general public, the Rancapanggung Village in particular and in general in the whole Cililin subdistrict, and outside the Cililin sub-district. The Bandung Regent at that time was RAA Wiranatakusumah V (Dalem Haji), during the reign of 1920-1921 and 19351942. The reign of Kadesh Haji Mukhtar in 1930-1942 was exactly the same as the leadership of R. Oto Iskandar Dinata as Chair of the Pasundan Circle of Friends (1930-1942).

According to the oral history of his offspring, Rd. Haji Mukhtar has a four wife with a vast land wealth. From one of his wives, Rd. Haji Mukhtar left a child who became a scholar / instructor with Falak science in Rancapanggung, named Haji Arifin (1907 - 1997).

The head of Rancapanggung Village in the colonial period was a pilgrimage, which is actually a historical exception because in general the pilgrims of the colonial era did not become subordinate to the Dutch, but instead took care of pesantren, became kyai and taught the Koran. Directly subordinate to the Dutch government were regents, civil servants in Java and uleebalang in Aceh.

However, the Rancapanggung Village website mentioned Rd. Haji Mukhtar "seen from his authority and strong influence in the eyes of the Dutch colonial," became very possible. The rest, because Cililin has long been known as the city of students, where Rd. Haji Mukhtar is one of the products that he is said to have sent to several pesantren to the Banten region and then became a pilgrimage. Cililin has long been called "the santri warehouse and hajj factory." The City of Santri is a term given to cities that have many boarding schools, including the western part of 
Bandung. According to data from the Ministry of Religion of West Java Province, there are more than 450 pesantren in West Bandung, mostly in the southern region.

The large number of pesantren cannot be separated from the historical value of 17th century Islamic da'wah brought to the Cililin region which was developed by one of the Sufi clerics from Banten who had a lineage to Cirebon and Demak, named Muhammad Syafi'i and Sheikh Abdul Manaf. Muhammad Syafi'i is known as the Prince of the Winds whose pilgrimage tombs are in the Pesantren Dawuan, Cijenuk, Cililin until now. Then, Sheikh Abdul Manaf was a scholar who left the pilgrimage site, the Tomb of Mahmud in Cigondewah. These two scholars were tasked with spreading Islam in the south Bandung region when the Banten Sultanate was ruled by the 16th century Sultan Maulana Yusuf (1568-1580) and the Cirebon Sultanate was ordered by Panembahan Ratu.

Rifkiyal Robani's writing on the Santripedia website, apparently derived from oral tradition, explains that the names of villages in the Cililin Kawedanaan area all originate from the atmosphere of the Islamization stopover carried out by Sheikh Muhammad Syafi'i. According to him, the emissary from the Banten Palace who first settled in the Cililin area was a wandering Sufi cleric named Muhammad Syafi'i and Sheikh Abdul Manaf. The two men initially stopped at a comfortable place while teaching Islamic teachings. The name of the place has until now been given the name 'Sindangkerta.' Sindang means stop, Kerta means comfortable or safe which has now become Sindangkerta District, before Gunung Halu.

From Singdangkerta, move to the north to continue the teachings of Islam and stop by somewhere. The name of this new place is named Kampung 'Panaruban.' 
Panaruban comes from takarrub means to draw closer to God Almighty. In Panaruban began teaching Islam through dhikr. The sound of the dhikr is echoed by the surrounding community which in Sundanese is called "ngagerendung". Over time the Panaruban village turned into a 'Gerendung' village. The word Gerendung can also be from the word gerendeng in Sundanese, which means a soft voice, dhikr of khafi (quiet).

The village of Gerendung was increasingly crowded by students who were going to study religion. Finally, the students gathered in the village. The gathering place for the students is called "Jenuk". Jenuk means gathering, which is known as Batur Jenuk Balarea means "everyone here, brother." Now the village's name has changed to 'Cijenuk' until now.

The development of the Cijenuk boarding school is more lively, especially when holding commemoration of the Prophet's Birthday. Various types of food are served including wet cakes. The making of wet cakes originated from the northern village of Cijenuk until now the village is named 'Citalem' (Talem means wet cake container). Citalem is now a village. At that time, they did not use food dishes made from industrial engineering materials such as basket, glass cups, and kettles. To accommodate drinking water, vegetable meat, palm wine (teres means lahang). Pan Violence means the artisan "totap." Always use "katung" which is short lodong. The shortergiven the name "bowl" or "katung isbekong". Making this katung from a village located west of Cijenuk. The name of this village until now was given the name 'Cipongkor.' Pongkor means short lodet or katung. Now Cipongkor is a district. 
After a long period of time, another Sufi cleric came from Cikundul Cianjur who held the rank of Wedana Dalem (Wedana Keraton). This person was given the nickname Grandfather Sangga Wadana until now. Sangga Wedana joined to settle in Cijenuk until he ended his life, and was buried in the Cijenuk tomb together or adjacent to the graves of Mohammad Syafi'i and Sheikh Abdul Manaf.

Cijenuk students who independently spread the teachings of Islam. There are four known students who preach to develop Islam. The first, named Nayaganta that established a boarding school on the banks of the Cipatik River. Until now the place was given the name Nunuk which means gathering. The second, named Nayaguna established a pesantren on the edge of the Citarum River. The place is now named Kampung 'Depok.' Depok means settlement or Padepokan. The river bank developed into a village named 'Citapen', which comes from the word Citepian. Third, Nurasidi is a writer of the Koran. He founded the famous boarding school Bongas, known by the nickname "Ulama Bongas". After his life ended buried at the top of the hill "Pasirpogor Cililin". The fourth, earned the nickname Dalem Kemuludan founded the Islamic Boarding School in Cinengah Gununghalu, and so on. Such is the search for Rifkiyal Robani. Although it makes sense, justifying the necessary sources of reinforcement in the form of texts.

The link between Cililin as a city of students, the number of pilgrimages and boarding schools to the history of islamization developed by Sheikh Muhammaf Syafi'i and Sheikh Abdul Manaf since the 17th century requires a deeper exploration of social history with credible manuscript sources. Hopefully the future will be increasingly explored by the next generation of history lovers. 


\section{E. CONCLUSION}

From the description above, it can be concluded, it seems clear that almost all of the important stages of Indonesian history were colored by the role of ulama, even long before the Indonesian state existed. Ulama is what fills and colors the dynamics of society and the history of the Indonesian Archipelago. When Indonesia stood up, it was created with the soul and breath that the ulama had built. 'Indonesia' is an 'imagined society' or a Vocabulary with the inherent characteristics. Like when we say the word "house," what we imagine is actually the characteristics, functions or identities attached to the word house, that is, buildings, human habitation, protect from heat and rain, and so on. If one of its features is removed, for example it does not protect the heat and rain; then surely he is not a 'house' but rather a 'roofless building.' Or the word 'human habitation' is omitted; also not a house, but an animal cage. Another example is the mosque. What is the identity attached to the mosque? Buildings, places of worship, Muslims. Eliminate one of its characteristics, then it is not a mosque or not necessarily a mosque. So, whether or not something depends on the identities or functions attached to it. The identity of Indonesia that has been created is religious, Muslim nation (the largest in the world), multicultural and multiethnic tolerance, open, moderate and democratic. These identities were built and created by the scholars through their blood, sweat, soul and body for centuries. Then, if there were no scholars there would be no Indonesia. Because Indonesia is a work of scholars! 


\section{REFERENCES}

Geertz, C. (1960). The Javanese Kijaji: The changing role of a cultural broker. Comparative Studies in society and history, 2(2), 228-249.

Hamka IV, S. U. I. (1981). Jakarta: Bulan Bintang.

Hasbullah, M. (2003). Asia Tenggara Konsentrasi Baru Kebangkitan Islam. Bandung: Fokusmedia.

Kartodirdjo, S. Marwati Djoened Poesponegoro, dan Nugroho Notosusanto. (1993). Sejarah Nasional Indonesia Jilid, 6. Jakarta: Balai Pustaka.

Kipping, M., Wadhwani, R. D., \& Bucheli, M. (2014). Analyzing and interpreting historical sources: A basic methodology. In Kipping, M., Wadhwani, R. D., \& Bucheli, M. (eds) Organizations in time: History, theory, methods. Oxford: Oxford University Press.

Noer, Deliar. (1985). Modern Islamic Movement in Indonesia, 1900-1942, Jakarta: LP3ES.

Rahman, M. T. (2016). Islam As An Ideal Modern Social System: A Study of Ali Shariati's Thought. JISPO: Jurnal Ilmu Sosial dan Ilmu Politik, 6(1), 42-51.

Rahman, T. (2013). 'Indianization'of Indonesia in an Historical Sketch. International Journal of Nusantara Islam, 1(2), 56-64.

Reid, A. (1988). Southeast Asia in the Age of Commerce, 1450-1680: The lands below the winds (Vol. 1). Yale University Press.

Rosidi, A. (2000). Ensiklopedi Sunda: Alam, manusia, dan budaya, termasuk budaya Cirebon dan Betawi. Pustaka Jaya. 
Snyder, T. (2010). Bloodlands: Europe between Stalin and Hitler. London: The Bodley Head.

Steenbrink, Karel. (1995). Kawan dalam Pertikaian; Kaum Kolonial Belanda dan Islam di In (1596-1942), Mizan Bandung. 